\begin{tabular}{|c|c|c|}
\hline Beitr. Ent. & Berlin & ISSN 0005-805X \\
\hline $49(1999) 2$ & S. $447-461$ & 13.09 .1999 \\
\hline
\end{tabular}

\title{
Change of species set and abundance along a short time gradient: The impact of weather conditions on the conservation of butterflies
}

\author{
With 6 figures
}

\section{STEFAN BRUNZEL and HENNING ELLIGSEN}

\begin{abstract}
Summary
In a species-poor region of a low-mountain area of Nordrhein-Westfalen (Germany) a butterfly monitoring scheme that was started in 1989-1991 and repeated in 1997 revealed changes in the species set and the frequency (abundance) of several species. In line with previous studies the impact of weather conditions on butterfly occurrence and frequency is discussed.

As regards the nine-year period from 1987-1995 weather conditions in the study area have become more favourable since 1989. An increase in the average monthly temperatures and the monthly amount of sunshine and a decrease in monthly rainfall was mainly recorded between 1989 and 1992. The increase was observed during the main flight period (April to September) as well as between October and March (possibly relevant for juvenile stages of several species).

Several xerothermophilous species never before recorded in the study area were found to have immigrated. Other species which had vanished during the last thirty years have notably recovered, although landscape structure and habitat conditions have remained basically unchanged.

The importance of favourable weather conditions for the immigration and recovery of rare or endangered species is discussed and compared to the effects of conservation management.
\end{abstract}

\section{Zusammenfassung}

In einer artenarmen Region im Märkischen Sauerland (Nordrhein-Westfalen) wurde 1989-1991 eine rasterfeldbezogene Dauerbeobachtung von Tagfaltern begonnen und 1997 wiederholt. Gegenüber 1989 . 1991 zeigten sich 1997 Unterschiede im Artenset und der Abundanz einiger Arten. In Ubereinstimmung mit anderen Untersuchungen wird diesbezüglich der Einfiu 3 von Witterungsbedingungen diskutiert.

In einem Betrachtungszeitraum von 1987 bis 1995 sind die Witterungsbedingungen im Untersuchungsgebiet seit 1989 gunstiger geworden. Die mittleren Monatstemperaturen und die monatliche Sonnenscheindauer sind vor allem zwischen 1989 und 1992 deutlich angestiegen, während die monatliche Niederschlagssumme stark abgenonmen hat. Dieser Anstieg war sowohl während der hauptsächlichen Falterffugzeit (April bis September) als auch von Oktober bis März (mőglicherweise fur Prăimaginalstadien relevant) festatstellen.

Einige vergleichsweise xerothermophile Arten konnten 1997 erstmals nachgewiesen werden. Andere, während der letzten 30 Jahre verschwundene Arten, wurden wiedergefunden. Mehrere Arten mit individuenarmen Vorkommen während der Erfassungen 1989-91 besaßen 1997 eine größere Zahl und individuenstäkere Vorkommen, obwohl sich weder die Landschaftsstrukturen noch die Habitatbedingungen im Untersuchungsgebiet wesentlich geänđert haben. Witterungsbedingungen werden hierfür als Ursache diskutiert und mit möglichen Auswirkungen von Habitatmanagement verglichen.

\section{Keywords}

Butterfly monitoring, species set, impact of weather conditions, Germany, nature conservation 


\section{Introduction}

In recent years, several - not exclusively xerothermophilous - species of different groups (e.g. spiders, grasshoppers, butterflies) have recognizably expanded their distribution ranges in different parts of Europe (e.g. BISHOP, 1990; MEINEKE, 1994; FOLLNER \& KLARENBERG, 1995; POLLARD \& EVERSHAM, 1995; BRUNZEL, 1996), and selected species have shown a regional recovery (e.g. THOMAS \& JONES, 1993; BRUNZEL, 1996; SETTELE et al., 1996). Climatic factors are considered to have a significant impact (EHRLICH et al., 1980; DENNIS \& BRAMLEY, 1985; POLLARD, 1988; BISHOP, 1990; POLLARD et al., 1995; DORDA, 1995; MANSKE, 1995; VAN STRIEN et al., 1997), but in some cases regional conservation management measures may also play an important role (e.g. WARREN, 1987a, b; BRUNZEL \& REICH, 1996).

During a three-year period (1989-1991) the butterfly-species set of a region comparatively poor in numbers of species in the southern Nordrhein-Westfalen (Germany) was recorded (BRUNZEL, 1992a, b). In 1997 this survey was repeated in order to detect changes in species set and abundance.

The aim of this study is first of all to demonstrate that a change in species set and abundance has occurred and then to answer the following question: What is the most probable reason for the change observed?

Therefore we discuss the implications of a few years of favourable weather conditions (mainly 1989-1992) and consider the possible effects of conservation management on butterfly occurrence and frequency. The aim of the study is not to show a longer-term change in climatic conditions.

\section{Study area and methods}

The study area of approximately $340 \mathrm{~km}^{2}$ is located in a low-mountain region (county Märkischer Kreis, about $50 \mathrm{~km}$ south of Dortmund) with elevations between 176 and $663 \mathrm{~m}$ above sea level (most parts above $400 \mathrm{~m}$ ) (Fig. 1). It is characterized by comparatively high annual rainfall (long term average between 1240 and $1380 \mathrm{~mm}$ ) and an average annual temperature of $7,9^{\circ} \mathrm{C}$ (Lüdenscheid), thus displaying considerable traits of atlantic climates. The landscape shows the typical small-scale structure of low-mountain regions in the middle of Germany with extended (spruce-) forests and pasture dominated agricultural parts on mainly acid soils (BRUNZEL, 1992a; BRUNZEL \& PLACHTER, 1997).

Between 1989 and 1991 the butterfly species set was recorded intensively for 45 days from April to September in 73 grid squares (see Fig. 1). 24 other grid squares were investigated less intensively and therefore used only for a qualitative comparison, just as data (occasional records) collected between 1992 and 1996 (see Papilio machaon). The 73 grid squares $\left(1 \mathrm{~km}^{2}\right)$ were selected to represent the habitat variety of the study area, following preliminary studies conducted in 1987 and 1988 and previous investigations carried out in 1908-14 and 19661974 (UFFELN, 1914; 1923; HARKORT, 1976). This framework should guarantee the registration of nearly the whole species set between 1989 and 1991. In each grid square the species were counted along a transect to gain an insight in the species abundance. The results (BRUNZEL, 1992a, b) were taken as the basis for the comparison.

In 1997 the same grid squares were investigated in the same way (same or adjacent dates, same transect routes) on 20 days (April - September) in order to compare species set and abundance. Although the 1997 survey was carried out at a lower intensity (fewer days) and in only one year, this does not matter if the aim is to show an increase in the frequency of species. 


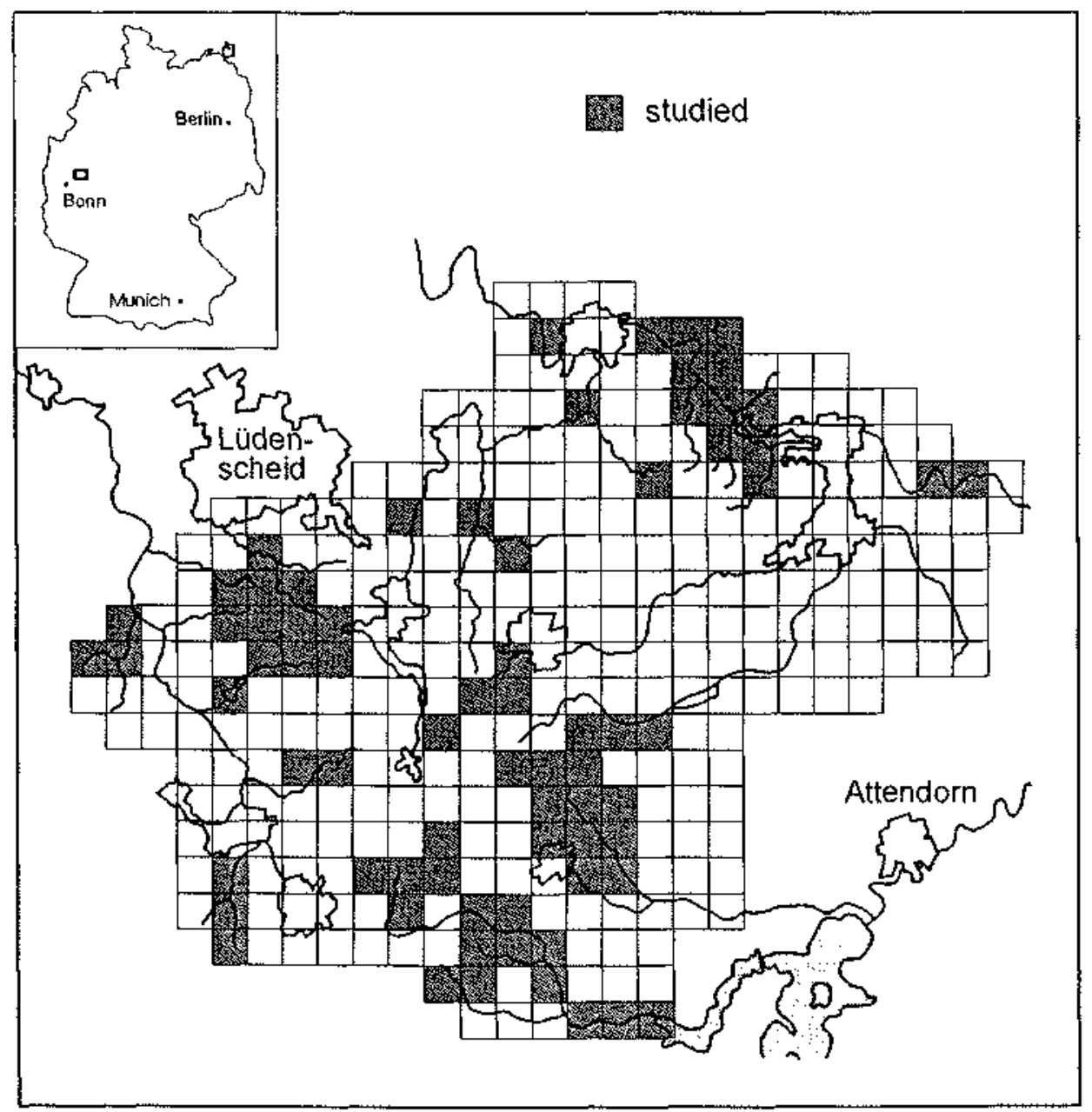

Fig. 1: Study area and studied grid squares (one grid square $=1 \mathrm{~km}^{2}$ ).

\section{Results}

\subsection{Change of species set}

The results of the survey in 1997 show a slight increase of species number from 35 (19891991) to 37 (Tab. 1) in spite of the rainy summer and the less intensive survey in 1997. Furthermore, many of the recorded species occurred in higher numbers than in 1989-1991. Referring to the change in species set over such a short period of time the occurrence of species not previously recorded in the study area, such as Erebia ligea and Papilio machaon, is of special interest. The first $P$. machaon ever recorded in the study area was obtained in August 1992 during the second generation of the species. In 1993 the species was found three times (first and second generation), in 1994 two times (1st and 2nd) and in 1995 only once (all observations made by chance). 1996 and 1997 it was no longer observed. The first generation records can be taken as indications for at least a periodical establishment in the study area (BRUNZEL, 1996). 
Tab. 1: Species set of the study area. Number of occupied grid squares: $I=1, I=2-4, I I=5-16,>16$, - = absent, $+=$ present (only qualitative data).

\begin{tabular}{|c|c|c|c|}
\hline Species & $1914-1923 / 1976$ & $1989-1991$ & 1997 \\
\hline Ochlodes venatus & + & $\Gamma \mathrm{V}$ & IV \\
\hline Thymelicus lineola & + & IV & IV \\
\hline Thymelicus sylvestris & + & IV & IV \\
\hline Papilio machaon & - & - & III' \\
\hline Colias hyale & + & II & I \\
\hline Gonepteryx rhamni & + & IV & IV \\
\hline Anthocharis cardamines & + & IV & IV \\
\hline Pieris brassicae & + & IV & IV \\
\hline Pieris napi & + & IV & IV \\
\hline Pieris rapae & + & IV & IV \\
\hline Celastrina argiolus & + & III & III \\
\hline Lycaena phlaeas & + & III & III \\
\hline Lycaena virgaureae & + & $\mathrm{I}$ & - \\
\hline Lycaena tityrus & + & - & II \\
\hline Neozephyrus quercus & + & III & I \\
\hline Plebeius argus & + & I & - \\
\hline Polyommatus icarus & + & III & III \\
\hline Polyommatus semiargus & + & II & I \\
\hline Satyrium w-album & - & $\bar{I}$ & II \\
\hline Thecla betulae & + & I & $\bar{I}$ \\
\hline Aphantopus hyperantus & + & IV & IV \\
\hline Coenonympha pamphilus & + & IV & IV \\
\hline Erebia ligea & - & - & $\mathrm{I}$ \\
\hline Maniola jurtina & + & III & IV \\
\hline Lasiommata megera & + & $I$ & II \\
\hline Argynnis aglaia & + & II & $\mathrm{I}$ \\
\hline Argymnis paphia & + & II & III \\
\hline Boloria aquilonaris & + & III & III \\
\hline Boloria selene & + & II & II \\
\hline Brenthis ino & + & III & IV \\
\hline Araschnia levana & - & III & IV \\
\hline Nymphalis c-album & + & $\Pi$ & III \\
\hline Nymphalis io & + & IV & IV \\
\hline Nymphalis polychloros & + & II & II \\
\hline Nymphalis urticae & + & IV & IV \\
\hline Vanessa atalanta & + & IV & IV \\
\hline Vanessa cardui & + & IV & II \\
\hline Limenitis populi & + & - & $\bar{\Pi}$ \\
\hline Apatura iris & + & III & III \\
\hline
\end{tabular}

${ }^{2}$ Records of 1992 to 1995. Not found in 1997.

The first ever records of two dayflying, moderately xerothermophilous moths Tyriajacobaeae and Callimorpha dominula (Arctidae) in 1990 and 1997 enhance the evidence for the immigration of some species into the study area. 


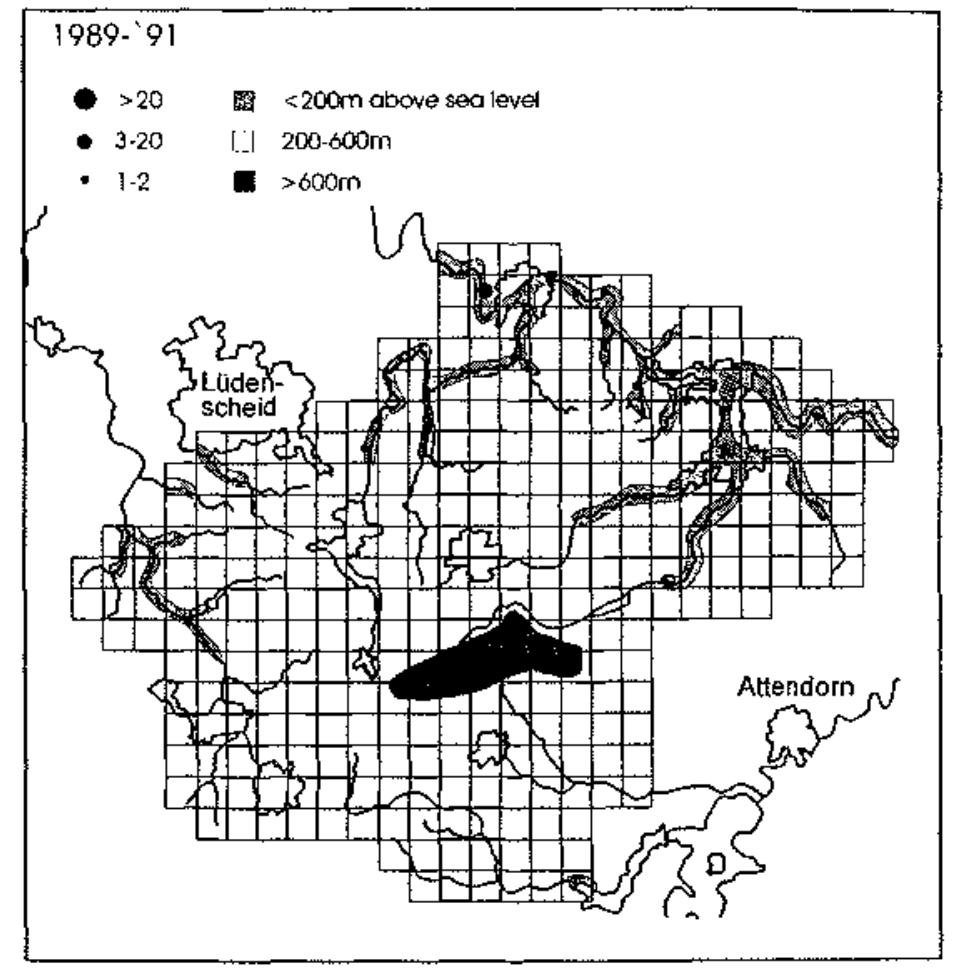

Fig. 2: Anaschnia levana: Number of individuals in studied grid squares. In each grid square, individuais were counted along the same transect routes (n) 1989-91 and 1997. The increase in courted individuals was significant (Mann-Whitney-U-Test: $u=24.5, \mathrm{p}<0.001, \mathrm{n}=16$ ).

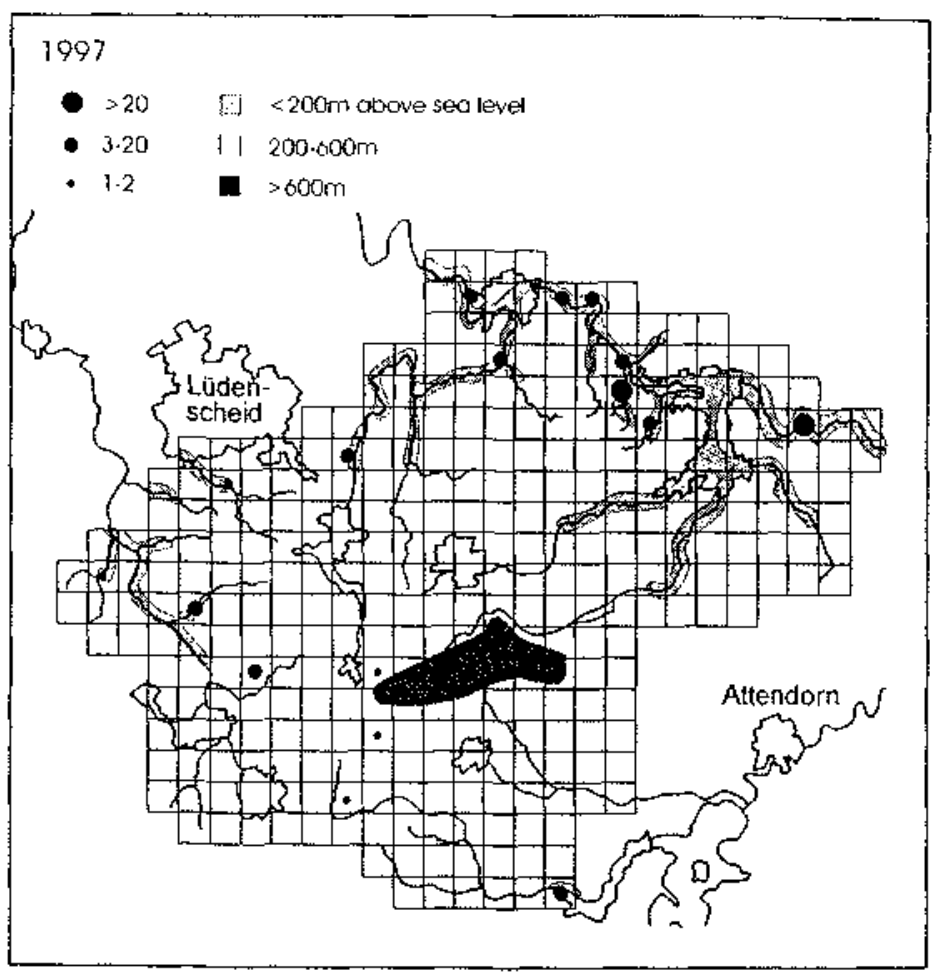



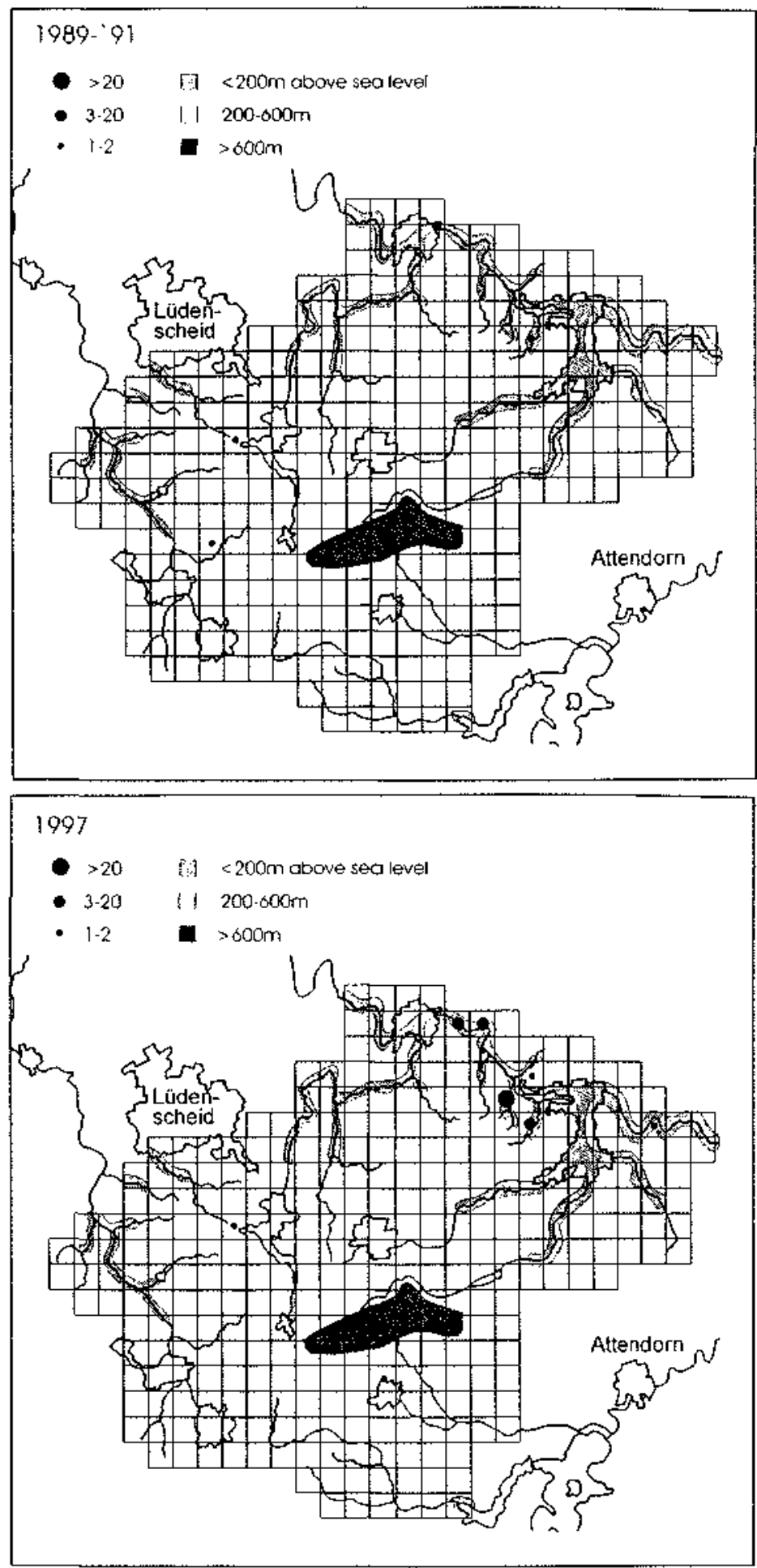

Fig. 3: Argynmis paphia:

Number of individuals in studied grid squares. In each grid square, individuals were counted along the same transect routes (n) 1989-91 and 1997. The increase in counted individuals was significant (Mann-Whitney-U-Test: $\mathrm{u}=11.5, \mathrm{p}<0.01, \mathrm{n}=9$ ). 


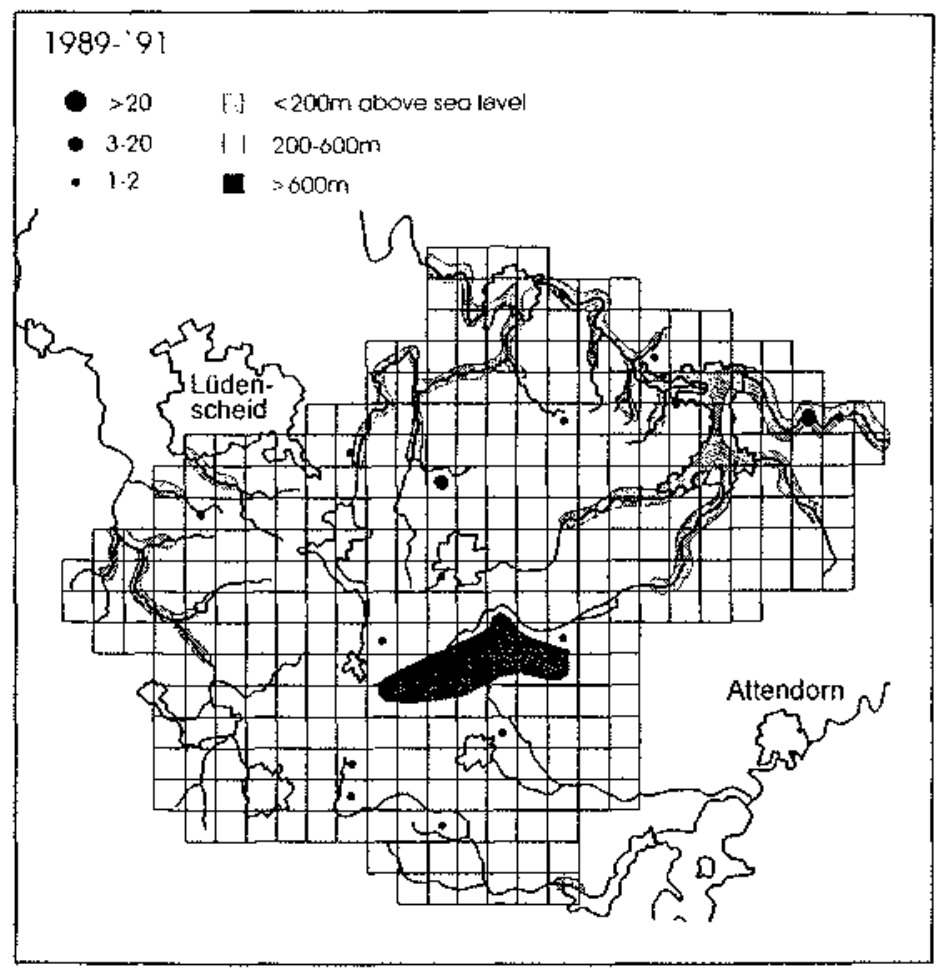

Fig. 4: Maniola jurtina:

Number of individuals in studied grid squares. In each grid square, individuals were counted along the same transect routes (n) 1989-91 and 1997. The increase in counted individuals was significant (Mann-Whitney-U-Test: $u=64.0, p<0.001, n=21$ ).

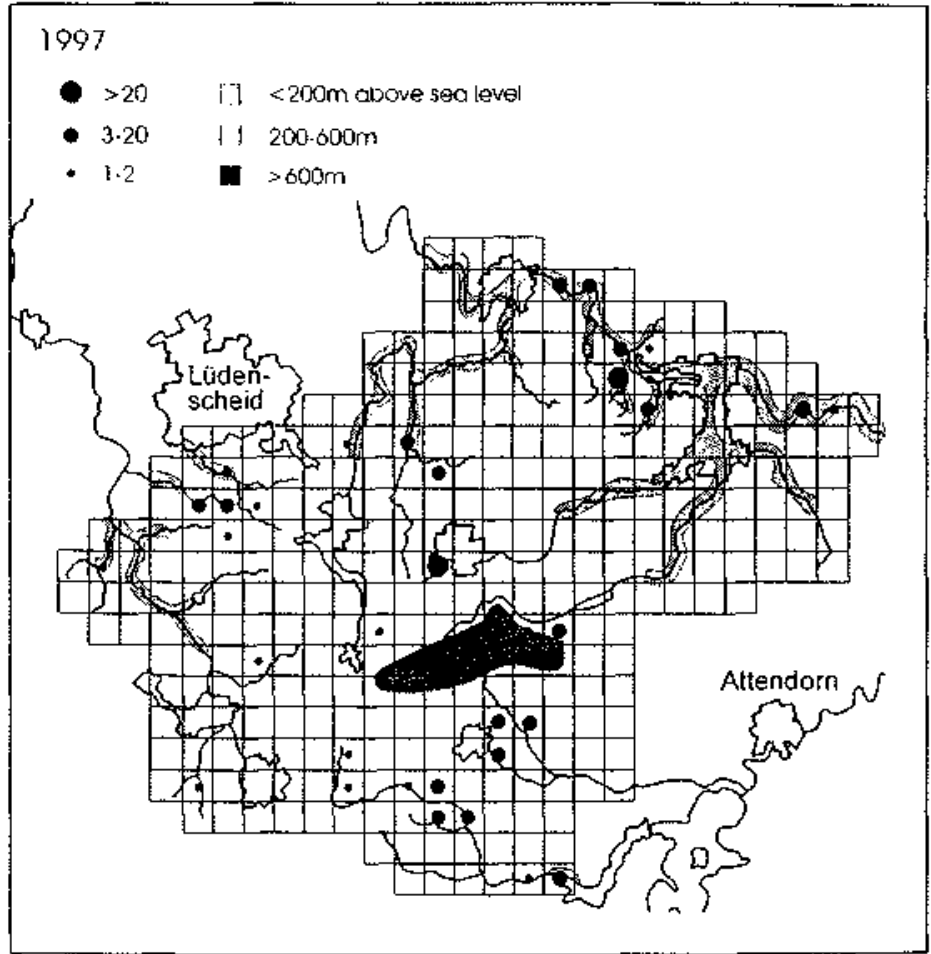


Two more species (Lycaena tityrus and Limenitis populi) had not been found since the early seventies. They were rediscovered and have been recorded three and two times, respectively, during 1997.

Considerable increases in frequency (number of records) and abundance between 1989-91 and 1997 have been found for Nymphalis c-album, Araschnia levana, Argynnis paphia and Maniola jurtina (Fig. 2, 3, 4). The abundance (number of recorded individuals) on the transect routes increased significantly (Mann-Whitney-U-test: $A$. levana: $\mathrm{u}=24.5 ; \mathrm{p}<0.001$; $\mathrm{n}=16 ;$ A. paphia: $\mathrm{u}=11.5 ; \mathrm{p}<0.01 ; \mathrm{n}=9 ; M$. jurtina: $\mathrm{u}=64.0 ; \mathrm{p}<0.001 ; \mathrm{n}=21 ; \mathrm{n}=$ number of transect routes). The three species had never vanished from the study area but were extremely rare at the end of the eighties (BRUNZEL, 1992a, b; see Fig. 2-4).

In the study area only Maniola jurtina inhabits managed and unmanaged sites and numbers have increased in both (Tab. 2). Thus, this is the only species for which the observed increase in frequency and abundance might also have been due to habitat managment. It was tested whether the increase on managed sites was greater than on unmanaged ones. No statistically significant difference was found $((2=0.201 ; \mathrm{df}=1 ; \mathrm{p}>0.05)$.

Tab. 2: Number of individuals of Maniola jurtina on transects 1989-1991 and 1997: Increase on managed and unmanaged sites.

\begin{tabular}{|c|c|c|c|c|}
\hline Site & \multicolumn{2}{|c|}{$1989-1991$} & \multicolumn{2}{|c|}{1997} \\
\hline & managed & unmanaged & managed & unmanaged \\
\hline 1 & 1 & - & 6 & - \\
2 & 1 & - & 9 & - \\
3 & 1 & - & 6 & - \\
4 & 1 & - & 14 & - \\
5 & 3 & - & 5 & - \\
6 & 1 & - & 2 & - \\
7 & 0 & - & - & - \\
8 & 0 & 2 & - & 2 \\
9 & - & 0 & - & 1 \\
10 & - & 2 & - & 0 \\
11 & - & 6 & - & 2 \\
12 & - & 1 & - & 10 \\
13 & - & 2 & - & 2 \\
14 & - & 0 & - & 3 \\
15 & - & 0 & - & 1 \\
16 & - & 0 & - & 8 \\
17 & - & 0 & - & 25 \\
18 & - & 0 & - & 4 \\
19 & - & 0 & - & 2 \\
20 & - & & & \\
21 & - & & & \\
\hline
\end{tabular}




\subsection{Species without a remarkable change in abundance or with a continuing decline}

Some species do not exhibit a change in frequency or abundance at all. This group (e.g. Argynnis aglaia, Boloria selene, Lycaena virgaureae) was recorded only one to three times between 1989 and 1991. They are more or less characteristic of mountain meadows, Nardusgrasslands and fens (plant communities of the Polygono-Trisetion, Violion caninae and Caricion fuscae) in the study area but also in most low-mountain regions of Germany (EBERT \& RENNWALD, 1991a, b). Their decline in the last thirty years is related to habitat destruction by man (Schweizerischer Bund für Naturschutz, 1988; EBERT \& RENNWALD, 1991a; b). Although most of these habitat types in the study area are under conservation management (with considerable success in the conservation of rare plant species), the group of butterfly species mentioned above has not shown any increase at all during the past nine years.

In contrast to most species in the study area one species has continued to decline: the tyrphophile butterfly Boloria aquilonaris. Both the number of populations and the size of most of the remaining populations have decreased rapidly: 5 of 11 populations have vanished since 1991 (BRUNZEL \& BUBMANN, 1994).

Two species (Lycaena virgaureae and Plebeius argus) were only found on one site in 1989 ' 91 (see Tab. 1). They vanished because of local habitat destruction.

Fig. 5: Average annual temperatures $\left({ }^{\circ} \mathrm{C}\right)$, sunshine / year (h) and annual rainfall (mm) 1987 1995.

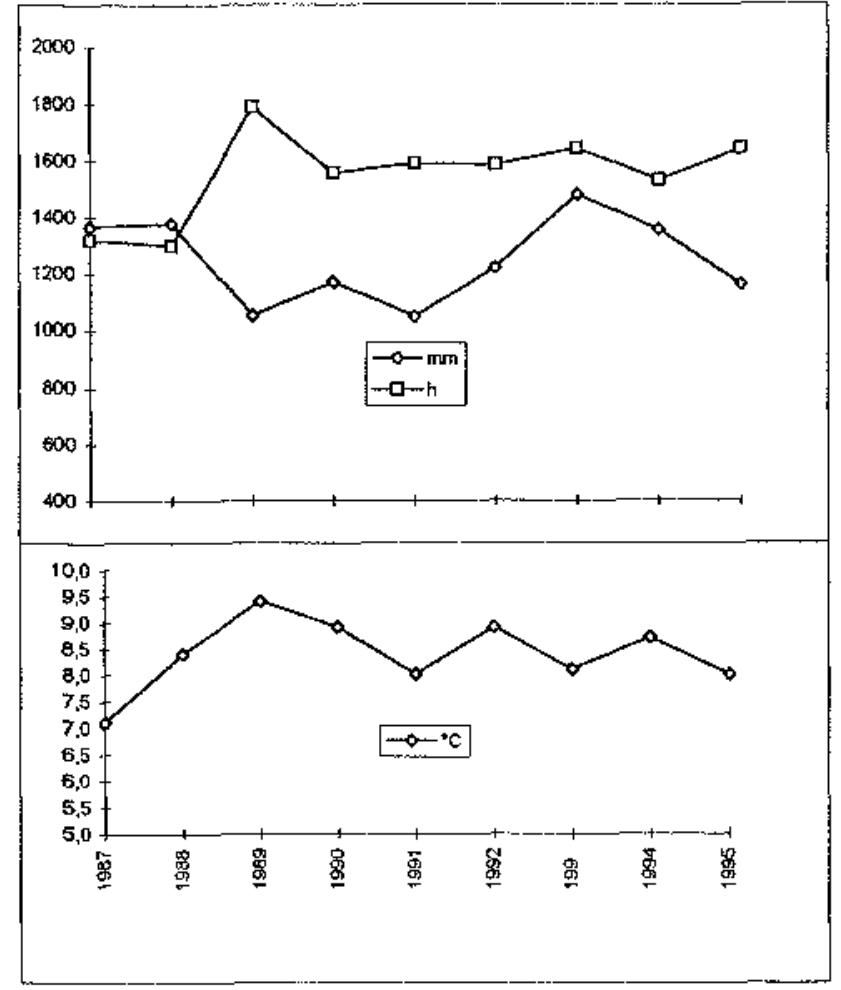

\subsection{Weather conditions from 1987 to 1995}

Mainly between 1989 and 1992 (-1995), a considerable increase of average monthly temperatures, especially during the main flight period (April to September), as well as between October and March is recognizable. At the same time, the hours of sunshine increased during 
the summer months while rainfall decreased. Several extreme values (hottest or sunniest month for more than thirty years) should be of special interest (e.g. July $1994: 21.0^{\circ} \mathrm{C}$ average; May 1989: 327 hours sunshine; July 1994: 275 hours sunshine). Even average annual temperatures and sunshine averages distinctly increased from 1989 to 1992 , while annual rainfall decreased during that period (Fig. 5) (Deutscher Wetterdienst, 1987-1995). None of the mentioned trends were significant over the whole 9-year-period (only sunshine tended to be: $r=0,5070 ; p<0,164$, Spearman's) because of conditions having turned less favourable since 1993 (e.g. rainfall). The years 1996 and 1997 appear to be following this change in trend (pers. comm. Wetterstation Luidenscheid) but the data are not yet available.

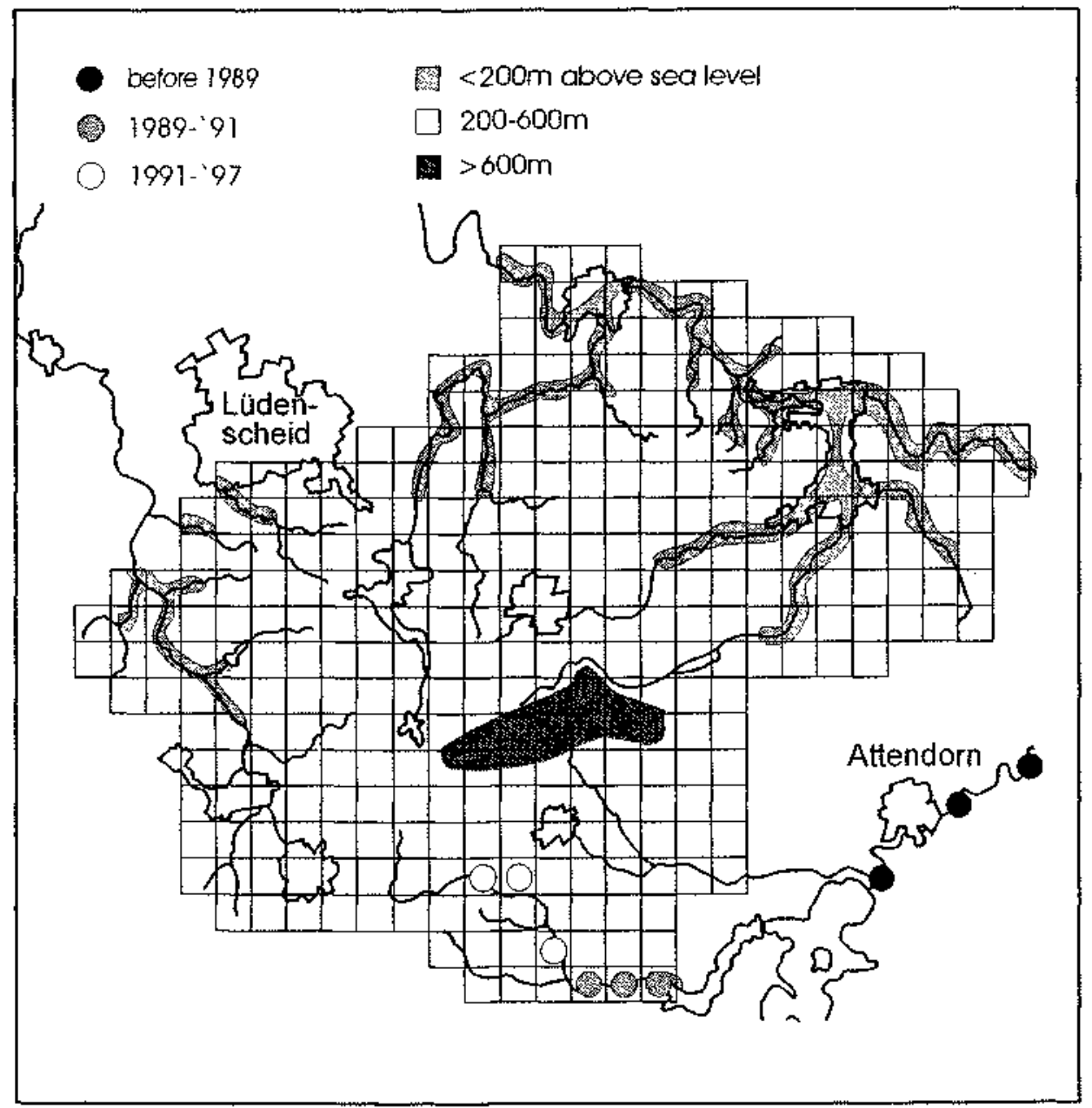

Fig. 6: Immigration of the moth Tyria jacobaeae.

\section{Discussion}

\subsection{Suspected migration routes used by selected species}

From 1989-1991, Araschnia levana was only observed in the lowest parts of the study area in one deep river valley and the valleys of a few tributaries. It seems to initially have dispersed 
along the river valleys. Meanwhile it has left the valleys and is now even found on more highly elevated plateaux (see Fig. 2).

The endangered and moderately xerothermophilous moth Tyriajacobaeae migrated into the study area in 1990, probably through the Lister river valley. It has dispersed along this valley and its tributaries to higher elevations, but has not yet been observed outside that river valley (Fig. 6).

\subsection{Changes observed}

The climatic data (chapter 3.3) lead to the hypothesis that the change of species set and species number from 35 (1989-1991) to 37 (1997) and the considerable increase of species frequency and abundance is caused by the more favourable weather conditions recorded mainly between 1989 and 1992. Although it is difficult to demonstrate that there is a change in the species set of the study area that is not related to "normal" year-to-year variances, the following facts indicate that this conclusion is feasible:

1. In comparison to the three years survey 1989 to 1991 four new species were found in 1997 (Limenitis populi, Lycaena tityrus, Erebia ligea, Papilio machaon). Three of them (Limenitis populi, Lycaena (ityrus and Papilio machaon) are taken to be moderately xerothermophilous (EBERT \& RENNWALD, 1991a, b), at least in the study area (BRUNZEL, 1992a, b).

2. The abundance and frequency of species such as Argymis paphia, Maniola jurtina, Araschnia levana or Nymphalis $c-a l b u m$ increased significantly. Except for $A$. paphia this has also been observed in other regions, e. g. the Netherlands and Flanders (MAEs \& VAN SwAAY, 1997; VAN SWAAY et al., 1997).

3. An immigration of moderately xerothermophilous moths (Tyria jacobaeae, Callimorpha dominula) which had not been recorded in the study area before was observed. Likewise, "new" species of other groups of arthopods, e.g. crickets (Phaneroptera falcata) or spiders (Argiope bruennichi) occurred.

Weather conditions had already changed in 1989. Therefore, first recorded species in the study area in 1991 (e.g. Thecla betulae and Lasiommata megera) could already be attributed to a change in species set, too.

Statistical approaches based on BMS-data (Butterfly Monitoring Scheme) of the United Kingdom and the Netherlands have shown that observed changes in butterfly numbers are not exclusively related to "normal" year-to-year variances (VAN STRIEN et al., 1997). These results can at least be taken as an indication that changes in species numbers and abundance could also have taken place in our study area. Our data-base, however, does not meet comparable requirements.

\subsection{Possible reasons for a change: weather conditions or effects of conservation management}

Although the frequency of records and counts of individuals (transect method) in each grid square as the main tool for comparing the situations in 1989-1991 and in 1997 do not meet the requirements for making detailed quantitative statements, the increase in frequency and abundance of at least some species seems to be worth discussing. But what is the main cause of the observed change? Weather conditions (favourable years 1989-1995, mainly 1989-1992) or conservational efforts (success) towards improving the habitats relevant for these species? 
The following considerations support the hypothesis that favourable weather conditions are the most probable reason for the observed change of species set and abundance in the study area:

1. Only a few habitats such as fens, mountain meadows and acidic Nardus-grasslands were conservationally managed, whereas no change in other landscape facilities was observed. However, the whole study area was affected by the change in weather conditions, especially the increase in temperature and sunshine periods in combination with less average rainfall.

2. Species inhabiting landscape structures or habitats which have not changed in quality or frequency (e.g. forest boundaries, deciduous forests) have become more frequent (Argynnis paphia, Araschnia levana, Nymphalis c-album) or have reoccurred (Limenitis populi).

3 . The study area has been species-poor. In comparison with species sets of nearby regions characterised by similar landscape structures, temperatures and elevations, but considerably less rainfall (e.g. BRUNZEL \& PLACHTER, 1997), the difference in the species set, especially of moderately xerothermophilous species, is remarkable.

4. Moderately xerothermophilous species (Papilio machaon, Tyria jacobaeae, Callimorpha dominula, Limenitis populi, Lycaena tityrus) have immigrated or re-occurred.

5. Previous studies dealing with the expansion of species (BISHOP, 1990; MENEKE, 1994; DORDA, 1995; FOLLNER \& KLARENBERG, 1995; BRUNZEL, 1996).

6. Butterfly species exhibited an unusually increased number of generations in 1989 and 1990 and showed premature emergence probably due to extremely high temperatures in spring 1989 and 1990 (STEINER, 1990).

7. Several other studies have indicated a major influence of weather conditions on butterfly numbers. They appear to markedly increase after warm and dry summers, (POLLARD 1988; POLLARD \& EVERSHAM, 1995; POLLARD et al,. 1995) leading to the hypothesis of a climatic restriction of many species (DENNIS 1993).

8. Only Maniola jurtina shows an increase on managed and unmanaged sites (see Tab. 2). Since, even in this case, the increase in frequency and abundance on managed and unmanaged sites is similar, the impact of favourable weather conditions seems to be of major importance.

Apart from Maniolajurtina, the other species inhabiting managed (mainly from abandonment to extensive use) and improved habitats (fens, mountain meadows, Nardus-grasslands) like Argynnis aglaia, Boloria selene, Lycaena virgaureae respond positively to neither management measures nor to more favourable weather conditions. A possible reason for this could be that conservation management has not yet had sufficient positive effects; or that these butterfly species need more time than others to respond to such changes.

Therefore, none of the species inhabiting managed sites so far exhibits an increase caused mainly by effects of conservation management.

Argynnis aglaia, Boloria selene and Lycaena virgaureae have been found only one to three times between 1989 and 1991 . In contrast, Maniola jurtina was present in at least 13 grid squares if only with few individuals (BRUNZEL, 1992a, b). A more favourable starting situation like this could explain the fast recovery of this species.

\subsection{Species conservation and climatic impacts}

In regard to conservational aspects, it is not the aim of the study to give recommendations for the management of butterfly species, but to discuss the differences in responding to more 
favourable weather conditions. In order to do so, the rare and endangered species in the study area have been divided into groups (following POLLARD \& EVERSHAM, 1995) according to the change measured and the strategy types (Tab. 3).

Tab. 3: List of the rare and endangered species in the study area, categorized according to their measured change. Species recorded only once were omitted from the lists. Strategy type and type of mobility following Schweizerischer Bund für Naturschutz, (1988), EBERT \& RENNWAID (1991a, b) and WEIDEMANN, (1995) although in a few cases the appropriate category seems to be doubtful ( $\mathrm{rs}=\mathrm{r}$-selected, $\mathrm{ks}=\mathrm{k}$ - selected; $\mathrm{r}=$ resident, $\mathrm{m}=$ mobile). ${ }^{\mathrm{a}} \mathrm{m}$ Species taken as moderately xerothermophilous, at least in the study area (BRUNZEL 1992a, b).

\begin{tabular}{|c|c|c|c|c|c|}
\hline \multicolumn{3}{|c|}{ Species with observed increase } & \multicolumn{3}{|c|}{ Species without increase or with decline } \\
\hline Papilio machaon ${ }^{\mathrm{B}}$ & rs & $\mathrm{m}$ & Polyommatus semiargus & $\mathrm{rs} / \mathrm{ks}$ & $\mathbf{r}$ \\
\hline Lycaena tityrus" & rs & $\mathrm{m} / \mathrm{r}$ & Thecla betula $e^{\mathrm{a}}$ & ks & $\mathrm{m} / \mathrm{r}$ \\
\hline Satyrium w-album ${ }^{\mathrm{a}}$ & $\mathrm{ks}$ & $\mathbf{r}$ & Argynnis aglaja & ks & $\mathbf{m} / \mathbf{r}$ \\
\hline Limenitis popula & $\mathrm{ks}$ & $\mathrm{m} / \mathrm{r}$ & Boloria selene & ks & $\mathbf{m} / \mathbf{r}$ \\
\hline Brenthis ino & $\mathrm{ks}$ & $\mathbf{r}$ & Boloria aquilonaris & ks & $\mathbf{r}$ \\
\hline Argynnis paphia & $\mathrm{rs} / \mathrm{ks}$ & $\mathrm{m} / \mathrm{r}$ & Nymphatis polychloros & Is & $\mathbf{m}$ \\
\hline Nymphatis c-album & rs & $\mathbf{m}$ & & & \\
\hline Araschnia levano ${ }^{\mathrm{a}}$ & is & $\mathrm{m} / \mathrm{r}$ & & & \\
\hline Maniola jurtina & $\mathrm{rs} / \mathrm{ks}$ & $\mathrm{m} / \mathrm{r}$ & & & \\
\hline $\begin{array}{l}\text { Lasiommata } \\
\text { megera }\end{array}$ & rs & $\mathrm{m} / \mathrm{r}$ & & & \\
\hline
\end{tabular}

Apparently, there is a dichotomy between the rare and endangered species in the study area in regard to their response to favourable weather conditions. A group of mainly r-selected and moderately xerothermophilous species which often show a high dispersal ability seems to be able to respond to more favourable weather conditions after a short time (e.g. Papilio machaon, Lycaena tityrus, Limenitis populi, Argynnis paphia, Nymphalis c-album, A. levana). One possible reason for this is: some of these were present but rare because of unsuitable longterm climatic conditions (e.g. M.jurtina, A. levana, N. c-album, L. megera) while other species, such as $P$. machaon or L. tityrus, appear to be able to invade quickly.

For this group, which includes highly endangered species, the main factor of influence on occurrence, recovery or population dynamics seems to be the weather conditions (regarding long-term climatic conditions). If they are favourable, specific landscape structures and habitat conditions would apparently be less important for several of these species.

The second group of mainly k-selected species does not appear to be able to recover or disperse (invade from regions where they are frequent) that rapidly, thus probably facing a greater danger of decline or extinction. These species have often a lower dispersal ability and does obviously not benefit from the same favourable weather conditions or from conservation management, at least not yet (e. g. Argynnis aglaia, Boloria aquilonaris, Boloria selene and Lycaena virgaureae). In case of species peferring climatic conditions of low-mountain regions or species with a boreo-alpine distribution (e. g. Boloria selene, Boloria aquilonaris), it is clear that they will not benefit from warm and dry years to the same extent. Others (Polymmatus semiargus, Boloria aquilonaris) are still declining because habitat deterioration continues on a local scale. 
But members of both groups are listed as similarly endangered on the relevant red data lists (e.g. LOLF 1986). As changes of distribution and abundance of several butterfly species become evident, conservation strategies must be adjusted to such circumstances (POLLARD \& EVERSHAM 1995). Obviously, as shown for the study area, there is considerably more need for conservation measures for the second group of species exhibiting no increase. Conservation strategies should therefore put more emphasis on the differences between species (e.g. different recolonization abilities) and between man-made or natural factors.

\section{Acknowledgements}

The investigation was financially supported by the "Nordrhein-Westfalen Stiftung fur Naturschutz, Heimat- und Kulturpflege", the "Untere Landschaftsbehörde Mărkischer Kreis" (MiCHAEL BuBMANN) and the "Naturschutzzentrum Mărkischer Kreis" (HANS OBERGRUBER). We thank BERNARD HACHMÖLLER and especially KIWI SCHUSTER for the stylistical review of the paper, HEIKE WORTH for her help producing the figures and Prof. Dr. HaRald Plachter, Prof. Peter Poschlod, Dr. Michael REICH and Dr. JOSEF SETTELE for their critical comments on the manuscript.

\section{References}

BISHOP, L. 1990: Meterological aspects of spider ballooning. - Environ. Entomol. 19(5): 1381-1388.

BRuNZEL, S. 1992a: Faunistisch-öKologische Untersuchungen der Tagfalterfauna des Südlichen Mărkischen Kreises (Märkisches Sauerland) I - Entomol. Z. 102(19): 345-361.

BRUNZEL, S. 1992b; Faunistisch-ðkologische Untersuchungen der Tagfalterfauna des Sudlichen Märkischen Kreises (Markisches Sauerland) U. - Entomol. Z. 102(20): 376-387.

BRUNZEL, S. 1996: Popilationsokologische Untersuchungen am Schwalbenschwanz (Papilio machaon L. 1758), - Z. Ökologie u. Naturschutz 5: $37-46$.

BRUNZEL, S. \& BUßMANN, M. 1994: Der Hochmoor-Perlmutterfalter (Boloria aquilonaris) in den Mooren des Ebbegebirges (Mărkischer Kreis, NRW). - EntomologischeNachr. Berichte 39(2): $73-79$.

BRUNZEL, S. \& REICH, M. 1996: Zur Metapopulationsstruktur des Roten Scheckenfalters (Melitaea didyma ESPER 1779) auf der Schabischen Alb. - Z. Okologie u. Naturschutz 5: 243-253.

BRUNZEL, S. \& PLACHTER, H. 1997: Regionalisierung der naturschutzfachlichen Bewertung am Beispiel von Tagfaltern (Lepidoptera, Rhopalocera) in zwei westdeutschen Naturräumen. - Vogel und Umwelt (in press).

DENNIS, R. L. H. 1993: Butterflies and climate change, - Manchester: Manchester University Press. $354 \mathrm{pp}$.

DENNIS, R. H. L. \& BRAMLEY, M. J. 1985: The influence of man and climate on dispersion patterns within a population of adult Lasiommata megera (Lepidoptera, Satyridae) at Brereton Heath, Cheshire (U.K.). - Nota lepid. 8: 309-24.

Deutscher Wetterdienst 1987-1995: Monatlicher Witterungsbericht. Amtsblatt des Deutschen Wetterdienstes 35.43 (1-12), - Offenbach/Main: Zentralamt Deutscher Wetterdienst.

DORDA, D. 1995: Isolation, Ausbreitungsstrategie und Makropterie beim Weinhähnchen (Oecanthus pellucens SCOP. 1763). - Z. Okologie u. Naturschut 4(3): 125-132.

EBERT, G. \& RENNWALD, E. 1991 a: Die Schmetterlinge Baden-Württembergs, Band 1. - Stuttgart: Verlag Eugen Uimer. - $5 \$ 2 \mathrm{~S}$.

EBERT, G. \& RENNwALD, E. 1991 b: Die Schmetterlinge Baden-Württembergs, Band 2. - Stuttgart: Verlag Eugen Ulmer. - $535 \mathrm{~S}$.

EHRIICH, P. R.; MURPHY, D. D.; SINGER, M. C.; SHERWOOD, C. B.; WHITE, R. R. \& BROWN, I. L. 1980: Extinction, Reduction, Stability and Increase: The response of Checkerspot Butterfly (Euphydryas) populations to the California drought. - Oecologia 46: 101-105. 
FOLLNER, K. \& KLARENBERG, A. 1995: Aetonautic behaviour in the wasp-like spider, Argiope bruennichi (SCOPO L) (Araneae, Argiopidae), - In: Proceedings of the $15^{\text {th }}$ European Collogium of Arachnology (V. RUZICKA, ed.). - Cesk. Budejovice. - p. 66-72.

HARKORT, W. 1976: Schmetterlinge in Westfalen (ohne Ostwestfalen); Fundortkartierungen und Fundortlisten, Stand Ende 1974, - Dortmund. Beitr. Landesk. 9: 33-102.

LöLF 1986: Rote Liste der in Nordrhein-Westfalen gefahrdeten Pflanzen und Tiere. - Schriftenreihe der Lölf 4. Recklinghausen. - $244 \mathrm{~S}$.

MANSKE, U. 1995: Freilandbeobachtungen zum Abflugverhalten makropterer Chorthippus parallelus (ZETTERSTEDT, 1821) (Acrididae: Gomphocerinae). - Articulata 10 (1): 61-72.

MAES, D. \& SWAAY, C. A. M. VAN 1997: A new methodology for compiling national Red Lists applied to butterflies (Lepidoptera, Rhopalocera) in Flanders (N-Belgium) and the Netherlands. - J. Ins. Conserv. 1: 113-124.

MEINEKE, T. 1994: Ausbreitungsversuche und initiale Populationsstadien von Chorthippus parallelus (ZETTERSTEDT, 1821) im Hochharz. - Articulata 9: 33-42.

POLLARD, E. 1988: Temperature, rainfall and butterfly numbers. - J. Appl. Ecol. 25: 819-828.

POLLARD, E. \& EVERSHAM, B. C. 1995: Butterfly monitoring 2 - interpreting changes. - In: Ecology and conservation of butterflies (A. PULIN, ed.): 23-36. - London: Chapman and Hall.

POLlaRD, E; Moss, D. \& YATES, T. J. 1995: Population trends of common British butterflies at monitored sites, - J. Appl. Ecol. 32: 9-16.

Schweizerischer Bund für Naturschutz, ed. 1988: Tagfalter und ihre Lebensräume. Arten-GefàhrdungSchutz. - Basel: SBN, - $516 \mathrm{~S}$.

SETTELE, J.; HENLE, K. \& BENDER, C. 1996: Metapopulation und Biotopverbund: Theorie und Praxis am Beispiel von Tagfaltem und Reptilien. - Z. Ökologie und Naturschutz 5: 187-206.

STEINER, A. 1991: Extreme Flugzeiten von Schmetterlingen in den Jahren 1989 und 1990 - Auswirkungen der weltweiten Klimaveränderung? - Atalanta 22: 237-244.

SwaAY, C. A. M. VAN; MaES, D. \& PLATE, C. 1997: Monitoring butterflies in the Netherlands and Flanders: the first results. - J. Ins. Conserv, 1: 81-87.

Thomas, C. D. \& JoNes, T. M. 1993: Partial recovery of a skipper butterfly (Hesperia comma) from population refuges: lessons for conservation in a fragmented landscape. - J. Anim. Ecol. 62: $472-481$.

UFFELN, K. 1913/14: Die Großschmetterlinge Westfalens. Nachträge und Berichtigungen. - Jahresber. westfäl. Frovinzialver. Wiss. u. Kunst $\mathbf{4 2}$ u. 45: 42-95.

UFFELN, K. 1923: Die Großschmetterlinge Westfalens. Nachträge und Berichtigungen. - Jahresber. westfal. Provinzialver. Wiss. $\mathfrak{u}$. Kunst 51 u. 52: 18-51.

Van Strien, A. J.; Van de Pravert, R; Moss, D.; Yates, T. J.; Van Sway, C. A. M. \& Vos, P. 1997: The statistical power of two butterfly monitoring schemes to detect trends. - J. Appl. Ecol. 34: 817-828.

WARREN, M. S. 1987a: The ecology and conservation of the Heath Fritillary Butterfly, Mellicta athalia II. - J. Appl. Ecol. 24: 483-498.

WARREN, M. S. 1987 : The ecology and conservation of the Heath Fritillary Butterfly, Mellicta athalia III. - J. Appl. Ecol. 24: 499-513.

WeIDEMANN, H. J. 1995: Tagfalter: beobachten, bestimmen. - Azigsburg: Naturbuch Verlag. - $659 \mathrm{~S}$.

\author{
Anschrift der Verfasser: \\ STEFAN BRUNZEL \\ Philipps-Universität Marburg \\ Fachbereich Biologie \\ Fachgebiet Naturschutz II \\ D- 35032 Marburg, Deutschland
}

HENNING ELLIGSEN

Gerhart-Hauptmann-Straße 10

D- 35039 Marburg, Deutschland 